\title{
Facilitation as a Personality-Centered Approach at the English Lessons at Secondary Schools
}

\section{Фасилітація як особистісно зорієнтований підхід на уроках англійської мови в закладах середньої освіти}

\author{
Nataliia Hupavtseva \\ PhD in Psychology, Assistant Professor, Department of Gene- \\ ral Psychology and Psychological diagnostics of Rivne State Uni- \\ versity of the Humanities (Rivne, Ukraine) \\ ORCID ID: https://orcid.org/0000-0002-8883-7686 \\ Researcher ID: AAC-2156-2019 \\ E-mail: natalahupavceva@gmail.com
}

\section{Наталія Хупавцева}

Кандидат психологічних наук, доцент кафедри загальної психології та психодіагностики, Рівненський державний гуманітарний університет, м. Рівне (Україна)

\section{ABSTRACT}

The purpose of our research is: to show the role of facilitation at the educational process at secondary school and to distinguish its main aspects; to underline the principles of the influence of perception on the process of studying English by schoolchildren.

Methods of the research. The following theoretical methods of the research were used to solve the tasks formulated in the article: a categorical method, structural and functional methods, the methods of the analysis, systematization, modeling, generalization.

Address for correspondence, e-mail: kpnu_lab_ps@ukr.net Copyright: (C) Hupavtseva Nataliia

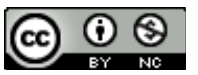


The results of the research. In our research we mean facilitation as a person-centered approach, expressed in a global trust of a person, postulating the actual tendency to grow, to develop and to realize his / her individual potential. It was shown that facilitation is a key concept of non-directive, client-centered or person-centered psychotherapy developed by C. Rogers. For understanding a sense of facilitative interaction the main principles of the theory of $C$. Rogers are: faith in original, constructive and creative wisdom of a man; the belief in the content of socio-personal nature means the actualization of the constructive personal potential of the individual in the processes of interpersonal communication; the main are the concepts of "necessary and sufficient conditions» of the interpersonal communication, facilitating personal development and providing constructive personal changes ("unconditional positive acceptance of another person", "active empathic listening", "congruent self-expression in communication"); the idea of the natural stages of the course of the group process that occurs in the indicated social and personal conditions, and of its equally regular therapeutic results.

It was underlined that it was very important for our research to distinguish between two types of learning (teaching): meaningless content and meaningful sense. The doctrine of the first type is compulsory, impersonal, intellectualized, evaluated from the outside, aimed at the assimilation of knowledge. The doctrine of the second type, on the contrary, is free and self-initiated, personally involved, affecting the whole personality, evaluated by the pupil himself/herself, with the aim to provide the assimilation of meanings as elements of personal experience. The main tasks of a teacher are stimulation and initiation (facilitation) of meaningful learning.

Conclusions. It was determined that socio-genetic mechanism of culture transmission was: to facilitate, to stimulate, to activate, to create favorable conditions, to give changes and make influences, to support, to help, to care, etc. Person's aspects of facilitation are: beliefs in the original, constructive and creative wisdom of man as a value. Formative influence of facilitation as a process is: conviction in the socio-personal nature that actualizes the constructive personal potential of the individual in the process of interpersonal communication. A result of facilitation is: the concept of the necessary and sufficient conditions for interpersonal communication, facilitating personal development and providing constructive personal changes.

Procedural side of facilitation at the English lessons at secondary school comprises the principles of synergy - cooperation, interaction, a dialogue; truth

(C) Hupavtseva Nataliia

DOI (article): https://doi.org/10.32626/2227-6246.2020-47.206-230 
and openness; acceptance and truth; empathic understanding; skills formation. The principles of facilitation in the process of interpersonal communication at the English lessons are: the development of the individual educational route, to provoke changes of pupils' person through a series of bifurcations, stimulating them to the process of creation, creating for this the conditions for interaction, proposing various feedbacks between the subjects of learning (mutual surveydialogue, interview, group forms of communication and training, etc.); conclusions according to individual and group contracts with pupils, organization of the learning process in dyads, forming communication groups, creating conditions for the formation of meaningful learning and personal development in general.

Key words: facilitative interaction, interpersonal communication, meaningless content, meaningful sense, facilitating personal development, positive acceptance of another person, active empathic listening.

\section{Introduction}

The reforms of general education in Ukraine and changes at secondary schools imply the achievement of a new qualitative level of school's activity, which meets the conditions and needs of our society. When preparing young people for inclusion into a complex network of numerous social, political, ethnic, cultural, psychological, everyday, personal and other connections in the society, the school must take into account the individual's needs and form a creative, active person capable to self-expression, self-improvement, self-esteem, being tolerant, understanding of the value of another person, abilities to communicate not only with a help of a native language, but at least by the help of one of the most common languages of the world.

Of particular importance in these circumstances there are studies of communication mechanisms, the discovery of productive conditions of the development of communicative activity at school practice in the process of learning a foreign language. The teacher faces the challenges of widespread use of active forms and teaching methods, which include, in particular, the use of technical means of training, giving more orientation to the profession of schoolchildren in future. 
The history of the methodology of teaching a foreign language knows a lot of attempts to find the most rigorous teaching methods. In Ukraine there are several different directions of intensive education, united under a general name «intensive training methodology». This one includes a sub-tendency (Mykhalchuck, 2017), the emotional-semantic method (Rose \& Gilbert, 1992), a pediatrician relaxation (Stephens, 1998), the rhythm pedagogy (Rose \& Gilbert, 1992), a method of activating the possibilities of the person (Гончарук \& Онуфрієва, 2018), the method of deepening (Newell \& Simon, 2009) and others. In $1978 \mathrm{~K}$. Scheingold \& A. Foundas (Scheingold \& Foundas, 1978) developed their own method of intensive study of a foreign language, which is realized through the activization of speech capabilities of a man on the basis of musical perception.

The most important means of learning, according to many scientists is the perceptual-emotional component of facilitative techniques, which has a great influence on the activation of speech capabilities of a person.

So, the purpose of our article is: to show the role of facilitation at the educational process at secondary school and to distinguish its main aspects; to underline the principles of the influence of perception on the process of studying English by schoolchildren.

\section{The tasks of the research}

1. To describe facilitation as a person-centered approach.

2. To understand the sense of facilitative interaction at the English lessons.

3. To distinguish between two types of learning (teaching): meaningless content and meaningful sense.

4. To describe main aspects of facilitation at the English lessons at contemporary secondary schools.

5. To show the principles of the influence of perception on the process of studying English by schoolchildren.

(C) Hupavtseva Nataliia

DOI (article): https://doi.org/10.32626/2227-6246.2020-47.206-230 


\section{Methods of the research}

The following theoretical methods of the research were used to solve the tasks formulated in the article: a categorical method, structural and functional methods, the methods of the analysis, systematization, modeling, generalization.

\section{Results and their discussion}

Facilitation is a person-centered approach, expressed in a global trust of a person, postulating the actual tendency to grow, to develop and to realize his / her individual potential. Facilitation is a key concept of non-directive, client-centered or person-centered psychotherapy developed by the prominent American psychologist, founder of the person-centered approach C. Rogers. Having arisen in the 40s years of the 20th century as a client-centered psychotherapy, a human-centered approach was developed in the 60-70s years. And, in such a case, in general the 20th century has been evolved into human-centered learning (Rogers, 2009).

For understanding a sense of facilitative interaction the main principles of the theory of C. Rogers are: faith in original, constructive and creative wisdom of a man; the belief in the content of socio-personal nature means the actualization of the constructive personal potential of the individual in the processes of interpersonal communication; the main are the concepts of «necessary and sufficient conditions» of the interpersonal communication, facilitating personal development and providing constructive personal changes («unconditional positive acceptance of another person», "active empathic listening", "congruent self-expression in communication"); the idea of the natural stages of the course of the group process that occurs in the indicated social and personal conditions, and of its equally regular therapeutic results (Rogers, 2009: 13).

It is also very important for our research that C. Rogers distinguishes between two types of learning (teaching): (C) Hupavtseva Nataliia

DOI (article): https://doi.org/10.32626/2227-6246.2020-47.206-230 
meaningless content and meaningful sense. The doctrine of the first type is compulsory, impersonal, intellectualized, evaluated from the outside, aimed at the assimilation of knowledge. The doctrine of the second type, on the contrary, is free and self-initiated, personally involved, affecting the whole personality, evaluated by the pupil himself / herself, with the aim to provide the assimilation of meanings as elements of personal experience. The main tasks of a teacher are stimulation and initiation (facilitation) of meaningful learning (Rogers, 2009: 18).

Considering the concepts of education, teaching, learning, C. Rogers emphasizes that in the modern world, characterized by constant changes, the emphasis onto the learning process must be shifted from teaching to facilitation of learning, as the manifestation of new thinking as a genuine reform of education, which cannot be achieved either by improving the skills and abilities, knowledge and abilities of a teacher, or by developing and introducing experimental programs and modern technical means into the learning process in general (Rogers, 2009: 22).

Facilitation is a process of stimulating the development of people's consciousness, their independence, freedom of choice, and not an attempt to make them dependent on a common opinion. Also facilitation is a change in the efficiency of activity of subjects of the activity. Freedom does not mean permissiveness from professional duties. If methodologists as leaders in education are able to realize their role as a facilitator, then the situation in education will potentially be changed.

A discussion concerning the terminological problem is preceded by the designation of six requirements, which, according to G. Ball \& M. Papucha, presented in the content of the term «facilitation». Firstly, the phenomenon itself must be objective and holistic in the system-functional sense. Secondly, the term should be unambiguous: to designate one phenomenon that has fairly strict boundaries. It is unacceptable to desig- 
DOI: https://doi.org/10.32626/2227-6246.2020-47 2020. випуск 47

nate a single term of several phenomena and, conversely, it is undesirable when a single phenomenon is indicated by several terms. The existence of synonyms is sometimes justified, and in some cases - inevitable. Thirdly, the etymological side of the issue should be taken into account. Fourthly, it is necessary, if it is possible, to take into account the prevailing traditions. Fifthly, it is necessary to separate the procedural and productive aspects of this phenomenon. Sixthly, it is necessary to take into account the terminology of related sciences, trying to avoid interdisciplinary contradictions (Балл \& Папуча, 2007: 64-68).

Considering these six most important phenomena of pedagogical reality and their corresponding concepts, the data on the actual state of affairs and the main proposals regarding the use of the term "facilitation» for clarity were summarized by us in a table (Table 1). The first column outlines the essence of the term under discussion briefly, which characterizes the dynamics of a person. This table also shows the main terms used to indicate the phenomenon (column 2) and its main components (columns 3, 4, 5). Moreover, in the terminological sense, the procedural side (columns 2, 3, 4) and the result of the process (column 5) were shown.

The main one in Psychology is a category that reflects the mechanism of cultural transmission from generation to generalization. According to N. Mykhalchuck \& E. Ivashkevych, in relation to the person there is a mechanism that ensures the formation of his / her personality. To denote the phenomenon under consideration, the unambiguous term «facilitation» is used - it is stimulating the development of people's consciousness, their independence and freedom of choice. To stimulate (from Latin) means to encourage, encourage action, to contribute, to give impetus, to serve inducing reason, to activate anyone to present personal activity (Mykhalchuck \& Ivashkevych, 2018).

(C) Hupavtseva Nataliia

DOI (article): https://doi.org/10.32626/2227-6246.2020-47.206-230 
Facilitation and its main aspects

\begin{tabular}{|c|c|c|c|c|}
\hline \multirow{2}{*}{$\begin{array}{l}\text { Facilita- } \\
\text { tion and } \\
\text { its main } \\
\text { sides (in } \\
\text { general } \\
\text { sense) }\end{array}$} & \multicolumn{4}{|c|}{ Terms for obtaining the main aspects of facilitation } \\
\hline & $\begin{array}{c}\text { Concept's } \\
\text { designation }\end{array}$ & $\begin{array}{l}\text { Person's } \\
\text { aspects }\end{array}$ & $\begin{array}{l}\text { Formative } \\
\text { influence }\end{array}$ & $\begin{array}{l}\text { A result of } \\
\text { facilitation }\end{array}$ \\
\hline 1 & 2 & 3 & 4 & 5 \\
\hline $\begin{array}{l}\text { 1. Socio- } \\
\text { genetic } \\
\text { mechanism } \\
\text { of culture } \\
\text { transmis- } \\
\text { sion }\end{array}$ & $\begin{array}{l}\text { Facilitate is } \\
\text { to stimulate, } \\
\text { to activate, } \\
\text { to create } \\
\text { favorable } \\
\text { conditions, to } \\
\text { give changes } \\
\text { and make } \\
\text { influences, } \\
\text { to support, } \\
\text { to help, to } \\
\text { care, etc. }\end{array}$ & $\begin{array}{l}\text { Beliefs } \\
\text { in the } \\
\text { original, } \\
\text { construc- } \\
\text { tive and } \\
\text { creative } \\
\text { wisdom } \\
\text { of man as } \\
\text { a value }\end{array}$ & $\begin{array}{l}\text { Conviction in } \\
\text { the socio-per- } \\
\text { sonal nature } \\
\text { that actualizes } \\
\text { the construc- } \\
\text { tive personal } \\
\text { potential of } \\
\text { the individual } \\
\text { in the process } \\
\text { of interperso- } \\
\text { nal communi- } \\
\text { cation }\end{array}$ & $\begin{array}{l}\text { The concept of } \\
\text { the necessary } \\
\text { and sufficient } \\
\text { conditions for } \\
\text { interpersonal } \\
\text { communica- } \\
\text { tion, facilita- } \\
\text { ting personal } \\
\text { development } \\
\text { and providing } \\
\text { construc- } \\
\text { tive personal } \\
\text { changes }\end{array}$ \\
\hline $\begin{array}{l}\text { 2. Proce- } \\
\text { dural side }\end{array}$ & $\begin{array}{l}\text { The principle } \\
\text { of synergy: } \\
\text { cooperation, } \\
\text { interaction, } \\
\text { a dialogue } \\
\end{array}$ & $\begin{array}{l}\text { Truth and } \\
\text { openness }\end{array}$ & $\begin{array}{l}\text { Acceptance } \\
\text { and truth }\end{array}$ & $\begin{array}{l}\text { Empathic un- } \\
\text { derstanding }\end{array}$ \\
\hline $\begin{array}{l}\text { 3. Trans- } \\
\text { ferring } \\
\text { know- } \\
\text { ledge - } \\
\text { learning }\end{array}$ & $\begin{array}{l}\text { Unconditio- } \\
\text { nal positive } \\
\text { acceptance } \\
\text { of another } \\
\text { person }\end{array}$ & $\begin{array}{l}\text { Person's } \\
\text { develop- } \\
\text { ment }\end{array}$ & $\begin{array}{l}\text { Self-actuali- } \\
\text { zation of the } \\
\text { person }\end{array}$ & $\begin{array}{l}\text { New solutions' } \\
\text { development }\end{array}$ \\
\hline
\end{tabular}


DOI: https://doi.org/10.32626/2227-6246.2020-47

\begin{tabular}{|c|c|c|c|c|}
\hline 1 & 2 & 3 & 4 & 5 \\
\hline $\begin{array}{l}\text { 4. Skills } \\
\text { Formation }\end{array}$ & \multicolumn{4}{|c|}{$\begin{array}{l}\text { Interpersonal communication, the development of the in- } \\
\text { dividual educational route. To provoke changes of pupils' } \\
\text { person through a series of bifurcations, stimulating them } \\
\text { to the process of creation, creating for this the conditions } \\
\text { for interaction, proposing various feedbacks between the } \\
\text { subjects of learning (mutual survey - dialogue, inter- } \\
\text { view, group forms of communication and training, etc.); } \\
\text { conclusions according to individual and group contracts } \\
\text { with pupils, organization of the learning process in dyads, } \\
\text { forming communication groups. Creating conditions for } \\
\text { the formation of meaningful learning and personal deve- } \\
\text { lopment in general }\end{array}$} \\
\hline $\begin{array}{l}5 . \text { Human } \\
\text { develop- } \\
\text { ment in } \\
\text { accordance } \\
\text { with } \\
\text { genetic } \\
\text { and social } \\
\text { programs }\end{array}$ & $\begin{array}{l}\text { Congruent } \\
\text { expression } \\
\text { in commu- } \\
\text { nication }\end{array}$ & \begin{tabular}{|l} 
The desire \\
to achieve \\
individual \\
goals, peaks \\
in profes- \\
sional \\
activities
\end{tabular} & $\begin{array}{l}\text { Active } \\
\text { empathic } \\
\text { listening }\end{array}$ & $\begin{array}{l}\text { Self-sufficien- } \\
\text { cy: spiritual } \\
\text { wealth of } \\
\text { inner content }\end{array}$ \\
\hline $\begin{array}{l}\text { 6. Impro- } \\
\text { ving the } \\
\text { behavior } \\
\text { of pupils }\end{array}$ & $\begin{array}{l}\text { Education of } \\
\text { orientation, } \\
\text { actualization } \\
\text { of will, mo- } \\
\text { tives, etc. }\end{array}$ & \begin{tabular}{|l|} 
Self-real- \\
ization in \\
achieving \\
knowledge, \\
in master- \\
ing new \\
values
\end{tabular} & $\begin{array}{l}\text { Awareness of } \\
\text { the importance } \\
\text { of learning, } \\
\text { based on the } \\
\text { characteristics } \\
\text { of interperso- } \\
\text { nal relation- } \\
\text { ships }\end{array}$ & $\begin{array}{l}\text { The restruc- } \\
\text { turing of per- } \\
\text { sonal attitudes } \\
\text { of pupils in } \\
\text { the process of } \\
\text { interpersonal } \\
\text { interaction }\end{array}$ \\
\hline
\end{tabular}

The stimulus (from Latin - Stimulus (chirped, chased)) is the effect that determines the activation of the psycho-physiological functions of the subject. The term «facilitation» is likewise used in Psychology. In Social Psychology, the concept of "Social Facilitation» is also used, which in its original meaning is interpreted as a trend that encourages people to better perform simple or well-known tasks in the presence of others; the modern meaning of the concept is the strengthening of the (C) Hupavtseva Nataliia

DOI (article): https://doi.org/10.32626/2227-6246.2020-47.206-230 
dominant human reactions in the presence of other people; reaction enhancing effect. In both the first and the second cases, we are talking about stimulating a person. Stimulation in the process of facilitation means "provoking changes in pupils' personality» (Rogers, 2009).

In such a way we shall underline that one of the main condition for successful learning a foreign language is the formation of a constant, constructive and intentional perception of English, which guarantees a living creative process of knowledge. The Latin word «recertio» denotes perception, a direct, coherent reflection of objective reality by the senses. This is a complex process of receiving and transforming information that provides reflection of objective reality, and the synthesis of feelings that are formed this process in general.

Is it permissible to consider the category of perception in connection with the facilitation? Of course, since perception is a starting point and a necessary component of the process of cognition and is more or less connected with thinking, memory, attention, it is directed by motivation and has an emotional color. Perception is always substantive. It always carries an object that is perceived in a real space. In our case, we call such an object a facilitative one.

By law, presented by G. Rose \& J. Gilbert, at first a general idea of the subject changes with a more definite and detailed perception. There are two types of perception:

- perception that occurs involuntarily and without desire;

- a complicated process of perception, which is directed by desire or volitional efforts (Rose \& Gilbert, 1992).

In accordance with the school curriculum, pupils have one way or another one to adopt (interact) with a foreign language, but the teacher should try to influence teenagers' perception of a foreign language in such a way that it becomes a complex process, directed by their will, and teaching a foreign language becomes a long, purposeful and systematic perception.

(C) Hupavtseva Nataliia

DOI (article): https://doi.org/10.32626/2227-6246.2020-47.206-230 
DOI: https://doi.org/10.32626/2227-6246.2020-47

A significant role is played by the preparation for perception, the knowledge of what exactly will be necessary to perceive under which conditions of perception will take place. Significant influence on the perception is given by our attitude to what we perceive, an interest in the object of perception, the feelings that it causes us, the desire or reluctance to perceive this object, the necessity or duty of the perception of an object or phenomenon.

We consider it as our main goal to teach pupils to comprehend a foreign language holistically and correctly understand it.

In the pedagogical process the law of unity of sensual, logical and practical must act. And the effectiveness of the educational process depends on:

- intensity and quality of sensory perception;

- logical comprehension of the perceived information;

- practical application of meaningful.

All these factors are, to our mind, facilitative ones.

Thus, the task of teachers in the classroom includes:

1) to intensify and make high-quality perception of a foreign language;

2) to use teaching methods of logical comprehension of the perceived information;

3) to teach pupils to apply already what has been perceived in practice.

Perception is inextricably linked with all peculiarities of the individual and depends on the past experience, knowledge, mental states and individual characteristics of a man (needs, inclinations, interests, motives, emotional states, etc.). Under the influence of these factors, an apperception is characteristic for each person, which causes significant differences in the perception of the same objects by different people or by the same person at different times. These factors need to be especially taken into account when working with creative pupils, when the individuality of each teenager manifests himself / herself particularly brilliantly. We should not forget that this (C) Hupavtseva Nataliia

DOI (article): https://doi.org/10.32626/2227-6246.2020-47.206-230 
category of schoolchildren is people, raised emotional, free and creative, with a more fragile nervous system and a special perception of the world. Probably, therefore, teachers need to be particularly careful in choosing the methods of pedagogical and psychological influences on the perception of a foreign language as on individuals, as well as on the team. With a small amount of training time, the ability to select and to organize the necessary information is important; it was able to interpret scientific knowledge, adapt it to the needs of practice, to popularize, that is, to convert specific scientific information about language into a form that is accessible to children. The most effective form is emotional, figurative perception of the materials, it contributes to the preservation of steady attention and interest, to deepen the motives of the educational process.

With which mechanisms is it possible to achieve constructive facilitative perception of a foreign language? In order to achieve the tasks the teacher has to develop positive emotions in the process of learning through such techniques as changing the methods of work, emotionality, to use activity of a teacher, to be interested in examples, witty remarks, etc. These receptions give not only temporary success, they solve the main task - to produce a steady, constant interest in the subject. Teachers should also choose from the pedagogical means the most economical and effective ones. In a dynamic, multifaceted pedagogical system, there are thousands of possible options for constructing and organizing educational activities, achieving the goals set. And only one of them will be the best in the existing specific conditions. The main task is to find it and to solve the problem by comparing possible options and assessing the available alternatives; intensify pupils, develop their abilities, independence.

To provide facilitative interaction at the lessons, teachers need:

- have the art of communication, choose the right tone and style of communication;

(C) Hupavtseva Nataliia

DOI (article): https://doi.org/10.32626/2227-6246.2020-47.206-230 
DOI: https://doi.org/10.32626/2227-6246.2020-47

- manage pupils' attention;

- determine the psychological states of pupils at the moment and take into account when choosing teaching methods;

- use techniques of theatrical pedagogy (for example, means of acting, methods of influencing the attention of the audience, expressive teacher's presentation of certain feelings, etc.).

The activities of the teacher should be carried out on the following principles:

- consciousness and activity (we must not forget that the main thing is not an object, but the person we create and the pupil who is not «an addition» to the subject, but the subject of his / her active development);

- vocabulary of teaching a foreign language (a large number of children think of forms, colors, sounds, feelings - hence the need for a visual education that is based on specific images);

- systematicity and consistency;

- strength (as in contemporary learning, thinking dominates over memory, then it is necessary to save pupils' strength, not to spend them on memorizing unimportant knowledge, preventing overloading memory to the detriment of thinking, not proceeding to study a new one, having not formed previous interest and a positive attitude towards it yet);

- accessibility (to avoid monotony, to teach figuratively, using bright facts and examples); tice.

- communication theory has to be combined with prac-

A prerequisite for any perceptual process is that universal mechanisms of perception which provides stabilization, categorization, selection, restriction of information. Perceptual image acts as a regulator of actions. At the same time, activity is a basic condition for the development of perception. What and how a person perceives depends on what and how it does. In practice, perception becomes an active, purposeful process of knowing reality.

(C) Hupavtseva Nataliia

DOI (article): https://doi.org/10.32626/2227-6246.2020-47.206-230 
Cognition is an instrument of human adjustment to the environment. The measure of the truth of the theory of facilitative interaction is its practical effectiveness in each situation. Practical expediency is a criterion of morality. Learning that builds on the interests of pupils and is associated with their life needs which bring better results. According to our views, a person begins to think when he / she encounters difficulties, the overcoming of which is important to him / her. Properly constructed training should be also problematic. The teacher should closely monitor the development of the interests of pupils, "throw» them into a position to understand and solve the problem. Pupils, in their turn, must be sure that, when they solve these problems, they acquire new and useful knowledge for themselves.

Indeed, for many pupils, a foreign language seems an insurmountable barrier that they can not overcome during their years of study. And this does not contribute to the successful perception of the subject. This is usually due to the fact that they do not have a clear understanding of the structure and mechanisms of the language, in our case, English. It is important to analyze the schemes of the actions of languages of polar types in simple examples.

Here are some examples of creative tasks.

For developing artistic skills: to depict the length of Grammar, or to draw consistent events of the day; "musicians» effectively memorize vocabulary and Grammar on songs; pupils who are fond of literature can translate poetry or small stories, compare different translations of the same text; «future directors" easily respond to the suggestion to recite, read and articulate semantic accents in the texts, play scenes, modeling monologues and dialogues, talk about the theater.

Typical tasks are: If you were a music instrument (a play, a picture etc.), which instrument would you be? Cause a direct live interest and impose imagination, emotions and thinking.

(C) Hupavtseva Nataliia

DOI (article): https://doi.org/10.32626/2227-6246.2020-47.206-230 
DOI: https://doi.org/10.32626/2227-6246.2020-47 2020. виПуск 47

Asking pupils after several years of study, which classes were captured in their memory as the most vivid, interesting and productive, what knowledge went into a long-term memory, they recall exactly those classes that caused them the most emotional and intellectual impressions.

By studying and analyzing the individual peculiarities of pupils, it is necessary to select the types of activities at the English lessons that would allow not only the best use of the expressive abilities of the perception of the surrounding world, inherent to the child, but at the same time engaging and developing less pronounced ones.

Thus, for the development of language abilities, pupils all together work with different types of dictionaries (bilingual, interpretative, phraseological, etc.), study the meaning of words, their origin, studying idioms. At the beginning they read prose and poetry to each other and to the whole class; read the same sentences (phrases, paragraphs with different emotional tones (funny, sad, happy, angry, etc.); use audio texts not only for listening, but also for writing them on paper, writing essays, articles, letters.

For pupils with mathematical abilities it is necessary to use those types of activities that contribute to the development of logic: the organization of sentences, paragraphs in a correct order (here it is necessary to pay attention to the order of words in English sentences: to speak and demonstrate what happens if the word is sometimes changed); the attribution of words or sounds to certain categories, classification. It is also worthwhile to use exercises that require critical thinking (for example, choose from a number of words the one that does not fit, and explain why). Reading stories, stopping from time to time and try to foresee the next event, give headlines to stories, articles, write instructions and so on.

Giving the visual and simple way of perception it is necessary to encourage the children to draw illustrations to the reader or listener and, conversely, to use drawings to stimulate (C) Hupavtseva Nataliia

DOI (article): https://doi.org/10.32626/2227-6246.2020-47.206-230 
reading, speaking, writing. Creating diagrams, charts, filling tables with information (for example, questionnaires), writing vertically or diagonally, using different speakers to select one or another language phenomenon helps to diversify the activity.

Writing letters / words with light touches on the palm / back of a classmate or in the air, the game "Carousel» (repeated pronunciation, moving around with a change of a partner), the manufacture of letters from plasticine, the use of magnetic letters for word-making on the board, the game «Moving dictation", pantomime and any other activities involving motions which help to develop kinesthetic abilities of perception.

Using music in the classroom not only increases the interest of children in learning and diversifies the lesson, but also helps to capture musical abilities, which facilitates the perception and learning material. Pupils enjoy using different familiar tunes for learning new lexical units, jazz bindings, flipping or stamping on accented warehouses or words, different rhymes, choral reading for processing intonation, reading of poetry for musical accompaniment, listening to short musicals passages that express the mood or subject of texts before listening them, which uniquely adjusts the children to this type of activity and facilitates the perception of audio text and also develops socio-cultural competence.

Participation in group discussions, discussion of one-onone issues with a desk companion, dramatization of dialogues, team games, work on a joint project, interviews - all these are types of activities for the development of extravagant perceptual abilities.

And for the development of introvert person it is expedient to use brainstorming, imaginary travel, to encourage writing their own stories, poems, preparing their own projects, making their own posters, leaflets, brochures.

And, finally, in order to fully utilize the naturalistic abilities of the child, it is more necessary to use activities by a (C) Hupavtseva Nataliia

DOI (article): https://doi.org/10.32626/2227-6246.2020-47.206-230 
model or analogy. The innumerable variety of teaching methods only confirms the principle: none of them is suitable for all pupils. Whatever the merits of this or that method, the universal «key», through which you can achieve outstanding results for all pupils in the class, does not exist. However, most teachers use the very same methods in working with children, without being able to detect and take into account their individual characteristics. Therefore, the success of children largely depends on how their characteristics correspond to the applicable teaching methods.

Pupils without motivation to study simply do not exist. Many pupils do not have time to study because they did not fit into the framework of a unified approach, because their individual characteristics do not correspond to the applicable teaching methods. This may be due to the peculiarities of perception of information and differences in the style of cognition.

Individual peculiarities of perception depend on functioning of the cerebral hemispheres. It is known that each hemisphere is not only responsible for the activities of the opposite side of the body, but also has its special functions, for example, responsible for analytical or synthetic reasoning. As a rule, one of the hemispheres of a human brain is dominant, leading, that is, determining one way or another one of knowledge and creativity. The left hemisphere is responsible for the analytical mind, mathematical abilities, abilities to work with scientific and technical literature; for people with the dominant left hemisphere dominated are verbal abilities and verbal-logical thinking. The right hemisphere is responsible for the synthetic reason, artistic ability, the ability to perceive artistic texts. People with the dominant right hemisphere have good orientation in space and coordination in movements.

Recently, the theory of the specialization of the cerebral hemispheres is increasingly used in Psychology and Pedagogy. On the basis of the research results of the brain, a holistic (C) Hupavtseva Nataliia

DOI (article): https://doi.org/10.32626/2227-6246.2020-47.206-230 
approach of teaching was created, based on a holistic, brain activity. The essence of the approach is to select the types of educational activities that contribute to the active, balanced activity of both hemispheres and to overcome some of the characteristic of learning difficulties by children.

In the first years of the child's life dominated by the right hemisphere, the relative prevalence of the left hemisphere becomes expressed to 8-10 years old. The model of education, adopted at our schools, kindergartens and even in families, is aimed for developing exclusively the left hemisphere. Thus, the learning style is dominant in our society and indirectly piercing all spheres of relations, leads to the formation of the left-half type of thinking.

The «left-wingers» are experiencing difficulties where it is necessary to move from the field of theory to practice where real conditions must be taken into account, and not manipulate schemes where it is not necessary to explain, but to act.

Among the pupils with a low level of success there are often «right-wing», which do not fit into the traditional model of education.

Also, when using the learning style, focused on the assimilation of the finished truths, there is a psychological barrier in the need for creative self-expression. At the same time, group aggression may appear in relations to those members of the team, who openly reveal creative abilities, differ in peculiarity and non-standard thinking.

In the vast majority of cases, only hearing and sight are used at the lessons, and the rest of the senses remain unnoticed. Tasks and exercises for the development of a right-wing type should include non-verbal components (music, singing, poetry, staging). The development of figurative thinking is more conducive to educational games. A significant part of the information is also perceived at the emotional level. 


\section{Conclusions}

It was determined that socio-genetic mechanism of culture transmission wass: to facilitate, to stimulate, to activate, to create favorable conditions, to give changes and make influences, to support, to help, to care, etc. Person's aspects of facilitation are: beliefs in the original, constructive and creative wisdom of man as a value. Formative influence of facilitation as a process is: conviction in the socio-personal nature that actualizes the constructive personal potential of the individual in the process of interpersonal communication. A result of facilitation is: the concept of the necessary and sufficient conditions for interpersonal communication, facilitating personal development and providing constructive personal changes.

Procedural side of facilitation at the English lessons at secondary school comprises the principles of synergy - cooperation, interaction, a dialogue; truth and openness; acceptance and truth; empathic understanding; skills formation.

The principles of facilitation in the process of interpersonal communication at the English lessons are: the development of the individual educational route, to provoke changes of pupils' person through a series of bifurcations, stimulating them to the process of creation, creating for this the conditions for interaction, proposing various feedbacks between the subjects of learning (mutual survey - dialogue, interview, group forms of communication and training, etc.); conclusions according to individual and group contracts with pupils, organization of the learning process in dyads, forming communication groups, creating conditions for the formation of meaningful learning and personal development in general.

Thus, summing up all of the above information, we must note that perception as a category of sensory knowledge is closely related to other concepts. Considering a foreign language as an integral system, we must note that only after passing the stages of sensual and intellectual cognition, perceived information can be used by pupils in their future professional activities. (C) Hupavtseva Nataliia

DOI (article): https://doi.org/10.32626/2227-6246.2020-47.206-230 


\section{Literature}

Балл Г. О., Папуча М. В. Діалогічність як форма існування і розвитку особистості. Ніжин : Міланик, 2007. 343 с.

Гончарук Н. М., Онуфрієва Л. А. Психологічний аналіз рівнів побудови комунікативних дій. Психолінгвістика. Психолингвистика. Psycholinguistics: Зб. наук. праць ДВНЗ «Переяслав-Хлельницький пед. ун-т ілені Григорія Сковороди». Переяслав-Хмельницький : ФОП Домбровська Я. М., 2018. Вип. 24 (1). С. 97-117. DOI 10.31470/2309-1797-2018-24-1-97-117.

Mykhalchuck N. O., Ivashkevych E. Z. Psycholinguistic features of the development of social intelligence of the teacher. Психолінгвістика. Психолингвистика. Psycholinguistics: Зб. наук. праць ДВНЗ «Переяслав-Хлельницький пед. ун-т ілені Григорія Сковороди». Переяслав-Хмельницький : ФОП Домбровська Я. М., 2018. Вип. 23 (1). С. 242-257. DOI 10.5281/zenodo.1211618.

Mykhalchuck N. O. Psychological context of the idea of understanding. Психолінгвістика. Психолингвистика. Psycholinguistics: Зб. наук. праць ДВНЗ «Переяслав-Хлельницький пед. ун-т ілені Григорія Сковороди». Переяслав-Хмельницький : ФОП Домбровська Я. М., 2017. Вип. 22 (1). С. 163-175.

Newell, A., \& Simon, H. (2009). Human problem Solving. New York : Englewood Cliffs. 920 p.

Rogers, C. R. (2009). A theory of therapy, personality and interpersonal relationship as developed in the client centered framework. New York : Mc. Grawn Hill. 80 p.

Rose, G., \& Gilbert, J. (1992). The power of form: A psychoanalytic approach to aesthetic form. Madison : International University Press.

Scheingold, K., \& Foundas, A. (1978). Rhymes for some reasons: Effect of rhyme on children's memory for detail and sequence in simple narratives. Vol. 43 (3), ch. 2, pp. 1231-1234.

Stephens, W. (1998). Hypotheses and Evridence. New York : Harper \& Row Publishers. 367 p.

\section{References}

Ball, H. O., \& Papucha, M. V. (2007). Dialohichnist yak forma isnuvannia $i$ rozvytku osobystosti [Dialogue as a form of the existence and the development of the personality]. G. O. Ball, M. V. Papucha (Eds.). Nizhyn : Milanyk [in Ukrainian].

Honcharuck, N. M., \& Onufriieva, L. A. (2018). Psykholohichnyi analiz rivniv pobudovy komunikatyvnykh dii [Psychological analysis of levels of communicative actions' constructing]. Psykholinhvistyka.

(C) Hupavtseva Nataliia

DOI (article): https://doi.org/10.32626/2227-6246.2020-47.206-230 
DOI: https://doi.org/10.32626/2227-6246.2020-47 2020. випУСК 47

Psikholingvistika. Psycholinguistics: Zb. nauk. prats DVNZ «Pereiaslav-Khmelnytskyi ped. un-t imeni Hryhoriia Skovorody - Psycholinguistics. Psycholinguistics. Psycholinguistics: Collection of Scientific Papers of the Pereiaslav-Khmelnytskyi Hryhorii Skovoroda State Pedagogical University, 24 (1), 97-117. Pereiaslav-Khmelnytskyi : FOP Dombrovska Ya. M. DOI 10.31470/2309-1797-2018-24-1-97-117 [in Ukrainian].

Mykhalchuck, N. O., \& Ivashkevych, E. Z. (2018). Psycholinguistic features of the development of social intelligence of the teacher. Psykholinhvistyka. Psykholinhvistyka. Psycholinguistics : Zb. nauk. prats DVNZ "Pereiaslav-Khmelnytskyi ped. un-t imeni Hryhoriia Skovorody Psycholinguistics. Psycholinguistics. Psycholinguistics : Collection of Scientific Papers of the Pereiaslav-Khmelnytskyi Hryhorii Skovoroda State Pedagogical University, 23 (1), 242-257. Pereiaslav-Khmelnytskyi : FOP Dombrovska Ya.M. DOI 10.5281/zenodo.1211618.

Mykhalchuck, N.O. (2017). Psychological context of the idea of understanding. Psykholinhvistyka. Psikholingvistika. Psycholinguistics: Zb. nauk. prats DVNZ «Pereiaslav-Khmelnytskyi ped. un-t imeni Hryhoriia Skovorody - Psycholinguistics. Psycholinguistics. Psycholinguistics: Collection of Scientific Papers of the Pereiaslav-Khmelnytskyi Hryhorii Skovoroda State Pedagogical University, 22 (1), 163-175. Pereiaslav-Khmelnytskyi : FOP Dombrovska Ya. M.

Newell, A., \& Simon, H. (2009). Human Problem Solving. New York : Englewood Cliffs.

Rogers, C. R. (2009). A theory of therapy, personality and interpersonal relationship as developed in the client centered framework. New York : Mc. Grawn Hill.

Rose, G., \& Gilbert, J. (1992). The power of form: A psychoanalytic approach to aesthetic form. Madison : International University Press.

Scheingold, K., \& Foundas, A. (1978). Rhymes for some reasons: Effect of rhyme on children's memory for detail and sequence in simple narratives. Vol. 43 (3), ch. 2, pp. 1231-1234.

Stephens, W. (1998). Hypotheses and Evridence. New York : Harper \& Row Publishers.

\section{Хупавцева Наталія. Фасилітація як особистісно зорієнтований підхід на уроках англійської мови в закладах середньої освіти}

\section{АНОТАЦІЯ}

Мета нашого дослідження - показати роль фасилітації в навчальному процесі у закладах середньої освіти та виокремити ії основні аспекти; (C) Hupavtseva Nataliia

DOI (article): https://doi.org/10.32626/2227-6246.2020-47.206-230 
підкреслити принципи впливу сприйняття на прочес вивчення англійської мови школярами.

Для розв'язання поставлених у статті завдань використовувалися такі теоретичні методи дослідження: категоріальний, структурно-функціональний, аналіз, систематизація, моделювання, узагальнення.

у дослідженні під фасилітацією ми мали на увазі особистісно зорієнтований підхід, виражений у глобальному почутті довіри до людини, у тенденції до особистісного зростання, розвитку та реалізації ії індивідуального потенціалу. Показано, що фасилітація є ключовою концепцією недирективної, зорієнтованої на клієнта чи особистісно зорієнтованої психотерапії, розробленої К. Роджерсом. Для розуміння сутності фасилітативної взаємодії основними принципами теорії К. Роджерса є: віра в оригінальну, конструктивну і творчу мудрість людини; віра у зміст соціально-особистісного характеру, що має на увазі актуалізацію конструктивного особистісного потенціалу особистості у процесах міжособистісного спілкування; основними є поняття «необхідні та достатні умови» міжособистісного спілкування, що сприяють розвитку особистості та забезпечують здійснення конструктивних особистісних змін («безумовне позитивне сприйняття іншої людини», "активне емпатійне слухання», "конгруентне самовираження у спілкуванні»); уявлення щодо реальних стадій перебігу групового процесу, що відбувається в певних соціальних та особистісно центрованих умовах.

Підкреслено, що для нашого дослідження дуже важливим було розмежування двох типів навчання: неусвідомленого й усвідомленого. Навчання першого типу $\epsilon$, так би мовити, "безособовим", інтелектуалізованим, оцінюється ззовні, спрямоване на опанування школярем знань. Навчання другого типу, навпаки, є самоініційованим, особистісно значущим, таким, що здійснює вплив на особистість загалом, оцінюеться самим вихованцем із метою забезпечити опанування сенсів (або сенсових фреймів) як елементів особистісно значущого досвіду. Основними завданнями вчителя $\epsilon$ стимулювання й ініціація (сприяння) усвідомленому навчанню.

Висновки. Визначено, що соціально-генетичним механізмом фасилітації є механізм передачі культури: «фасилітувати» означає «стимулювати, активізувати, створювати сприятливі умови, вносити зміни та впливати, підтримувати, допомагати, піклуватися» тощо; "віра в оригінальну, конструктивну і творчу сутність людини як самоцінність».

(C) Hupavtseva Nataliia

DOI (article): https://doi.org/10.32626/2227-6246.2020-47.206-230 
DOI: https://doi.org/10.32626/2227-6246.2020-47

2020. випУск 47

Базовим впливом фасилітативної взаємодії як процесу є переконання в соціально-особистісному характері фрасилітації, що актуалізує конструктивний особистісний потенціал особистості у процесі міжособистісного спілкування. Результатом фасилітації $є$ поняття щодо необхідних і достатніх умов для здійснення ефективного міжособистісного спілкування, що сприяють розвитку особистості та забезпечують конструктивні особистісні зміни.

Процедурною стороною фасилітації на уроках англійської мови в закладах середньої освіти є принципи синергії: співпраця, взаємодія, діалог; правдивість і відкритість; прийняття іншої людини та правдивість; емпатійне розуміння; формування потрібних навичок і вмінь.

Принципами фасилітативної взаємодії у процесі міжособистісного спілкування на уроках англійської мови є: розробка індивідуального навчального маршруту; провокування особистісних змін учнів через низку навчальних задач, що вміщують ситуації когнітивного дисонансу, стимулюючи школярів до прочесу їх створення, забезпечуючи позитивні умови для взаємодії, пропонуючи різні точки зору щодо змістових компонентів навчання (взаємне опитування - діалог, співбесіда, групові фрорми спілкування та навчання тощо); висновки за індивідуальними та груповими завданнями з учнями; організація навчального процесу в діадах; формування комунікативних груп; створення умов для формування змістового навчання й особистісного розвитку учнів.

Ключові слова: фасилітативна взаємодія, міжособистісне спілкування, неусвідомлене навчання, усвідомлене навчання, фасилітація особистісного розвитку, позитивне сприйняття іншої людини, активне емпатійне слухання.

Хупавцева Наталия. Фасилитация как личностно ориентированный подход на уроках английского языка в учреждениях среднего образования

\section{АННОТАЦИЯ}

Цель нашего исследования - показать роль фасилитации в учебном прочессе в учреждениях среднего образования и выделить ее основные аспекты; обозначить принципы влияния восприятия на процесс изучения английского языка школьниками.

Для решения поставленных в статье задач использовались следующие теоретические методы исследования: категориальный, структур(c) Hupavtseva Nataliia

DOI (article): https://doi.org/10.32626/2227-6246.2020-47.206-230 
но-функциональный анализ, систематизация, моделирование, обобщеHue.

В исследовании под фасилитацией мы имели в виду личностно ориентированный подход, выраженный в глобальном чувстве доверия к человеку, в тенденции к личностному росту, развитию и реализации индивидуального потенциала. Показано, что фасилитация является ключевой концепцией недирективной, ориентированной на клиента или личностно ориентированной психотерапии, разработанной К. Роджерсом. Для понимания сущности фасилитативного взаимодействия основные принципы теории К. Роджерса были положены в основу исследования: вера в оригинальную, конструктивную и творческую мудрость человека; вера в содержание социально-личностного характера взаимодействия, что подразумевает актуализацию конструктивного личностного потенциала человека в процессах межличностного общения; для понимания содержания фасилитативного взаимодействия основными понятиями являются: “необходимые и достаточные условия» межличностного общения, которые способствуют развитию личности и обеспечивают осуществление конструктивных личностных изменений («безусловное положительное восприятие другого человека», "активное эмпатийное слушание», "конгруэнтное самовыражения в общении»); представления о реальных стадиях группового процесса, происходящего в определенных социальных и личностно центрированных условиях.

Подчеркнуто, что для нашего исследования очень важным было разграничение двух типов обучения: неосознанного и осознанного. Обучение первого типа является, так сказать, "безличным», интеллектуализированным, оценивается извне, направленным на овладение школьниками знаний, умений и навыков. Обучение второго типа, наоборот, является самоинициированным, личностно значимым, таким, которое оказывает влияние на личность в целом, оценивается самим воспитанником с целью обеспечения процесса овладения смыслами (или смысловыми фреймами) как элементами личностно значимого опыта. Основными задачами учителя являются стимулирование и инициация (содействие) школьнику в процессе учебы.

Выводы. Определено, что социально-генетическим механизмом фасилитации является механизм передачи культуры: "фасилитировать» означает «стимулировать, активизировать, создавать благоприятные условия, вносить изменения и влиять, поддерживать, помогать, 
DOI: https://doi.org/10.32626/2227-6246.2020-47 2020. випуск 47

заботиться»; "вера в оригинальную, конструктивную и творческую сущность человека как самоценность». Базовым влиянием фасилитативного взаимодействия как процесса является убеждение в социально-личностном характере фасилитации, что актуализирует конструктивный личностный потенциал в процессе межличностного общения. Результатом фасилитации является понятие о необходимых и достаточных условиях для осуществления эффрективного межличностного общения, что, в свою очередь, способствует развитию личности и обеспечивает конструктивные личностные изменения.

Процедурной стороной фасилитации на уроках английского языка в учреждениях среднего образования являются принципы синергии: сотрудничество, взаимодействие, диалог; правдивость и открытость; принятие другого человека; эмпатийное понимание; формирование необходимых навыков и умений.

Принципами фрасилитативного взаимодействия в процессе межличностного общения на уроках английского языка являются: разработка индивидуального для каждого ученика учебного маршрута; провоцирование личностных изменений учащихся с помощью целого ряда учебных задач, содержащих ситуации когнитивного диссонанса, что стимулирует школьников на создание положительных условий для взаимодействия, предлагая различные точки зрения касательно содержательных компонентов обучения (диалог, собеседование, групповые формы общения и обучения и т. д.); организация учебного процесса в диадах; формирование коммуникативных групп; создание условий для формирования содержательного обучения и личностного развития учащихся.

Ключевые слова: фасилитативное взаимодействие, менличностное общение, неосознанное обучение, осознанное обучение, фасилитация личностного развития, положительное восприятие другого человека, активное эмпатийное слушание.

Original manuscript received December 17, 2019 Revised manuscript accepted January 25, 2020 